\title{
GABRIEL INZAURRALDE. La escritura y la furia. Ensayos sobre la imaginación
}

latinoamericana. Leiden: Almenara, 2016. 290 pp. ISBN 978-90-822404-9-8.

La escritura y la furia de Gabriel Inzaurralde abre con una introducción seguida de cinco estudios en los que aborda a Julio Cortázar, Juan Carlos Onetti, Ricardo Piglia, Fernando Vallejo, Roberto Bolaño y Mario Levrero. Inzaurralde menciona que estos artículos fueron escritos a lo largo del tiempo y dan cuenta de "entusiasmos teóricos de intensidad y duración variables" (16) cuya finalidad, según indica el autor, no es sino la de generar otras posibilidades de lectura. Aunque podríamos añadir que, además de sugerir otras lecturas sobre los autores estudiados, este texto relanza una discusión que se ha venido hilvanando a lo largo del tiempo: la utilidad de la crítica literaria.

Ya desde las páginas introductorias "La crítica literaria como artefacto insufrible", en cuyo título encontramos el eco de Bolaño, Inzaurralde plantea el debate sobre la pertinencia que en pleno siglo XXI pueden tener todavía la crítica o la teoría literarias. El tono provocador abre la puerta a una fructífera discusión que va desde los intentos por sistematizar estas disciplinas "por naturaleza indisciplinadas", a las "incursiones rapaces" que se hacen a otras, tales como la historia, la antropología, la lingüística, el sicoanálisis, la semiótica o la filosofía, para "asediar los textos de ficción” (9). El bosquejo acerca de la situación y la función que conllevan actualmente la teoría y la crítica literarias lleva al autor a concluir provocativamente que, dados los cambios sufridos en su uso, "la crítica de la literatura está tendencialmente condenada a desaparecer" (9). Inzaurralde remarca que, lo que otrora fuera justificado por el interés de legitimar las literaturas nacionales y canónicas que constituían "la identidad espiritual de una nación" (10) ha perdido su total relevancia hoy en día. Del mismo modo, los programas de enseñanza actuales han dejado de lado -o bien han eliminado- a la literatura como materia de estudio. Convertida en producto, la literatura ha derivado en un "consumidor depurado" (10) cuyo interés no está ya en las reyertas ni en la mediación reflexiva que puede aportar la crítica. Son líneas escritas con "furia" -que reenvía al título del libro- cuyo tono irónico invita a relanzar la discusión sobre el uso y la supervivencia de la teoría y la crítica literarias.

En el primer ensayo se analizan dos cuentos, uno de Cortázar y otro de Onetti, tomando como hilos conductores los conceptos de rito de pasaje (Walter Benjamin), subjetividad (Merleau-Ponty), espacio o lugar (Michel de Certeau), acontecimiento o sujeto (Alain Badiou) e imagen dialéctica (Didi-Huberman), entre otros, que se irán entretejiendo para dar lugar a una muestra in situ de las incursiones rapaces que hace la literatura a otras disciplinas y teorías que permiten leer de una forma distinta a Cortázar y a Onetti sin que por ello se trate aquí de una lectura cruzada de estos autores. El cuento "El otro cielo" (1966) de Cortázar permite analizar los desplazamientos

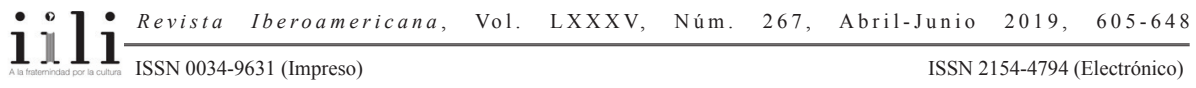


espaciotemporales a nivel histórico, entre pasado y presente, sueño y realidad, infancia y edad adulta, así como entre múltiples intertextualidades literarias. Lo que demuestra que, más que marcar la separación, las fronteras son el sitio en donde los contrastes están más próximos. De Onetti, se analiza el cuento "Un sueño realizado" (1941) y, aunque se toman como punto de partida las fronteras que se delimitan entre los dos personajes masculinos, resulta particularmente interesante la discusión que entabla Inzaurralde, cuyo conocimiento sobre Onetti es patente, sobre las interpretaciones del tercer personaje, la mujer, que abarca la mayor parte del estudio. Aquí, Inzaurralde propone otro análisis de ésta que discrepa totalmente del que han convenido otros estudios críticos, ofreciendo de este modo una lectura reactualizada del relato.

En el segundo estudio sobre Plata quemada (1997) de Ricardo Piglia, se discuten las distintas críticas existentes sobre el texto mismo, así como los debates en torno a su premiación en 1997. Y al igual que hace con Onetti, Inzaurralde refuta a algunos críticos para -mediante la mención de otros textos de Piglia-inscribir esta novela en la continuidad de la constelación pigliana. En este diálogo con la crítica, Inzaurralde confirma el rol de ésta como mediación de la lectura al tiempo en que se reitera su pertinencia y se le devuelven sus cartas de nobleza.

El tercer análisis, está dedicado a La virgen de los sicarios (1994) de Fernando Vallejo. Y aunque se recurre principalmente a los conceptos de Ángel Rama, otras posturas mencionadas para analizar el espacio son también sugerentes (Levi-Strauss, Casey, Sloterdijk, Flores Galindo). Si bien el análisis central lo constituye el deambular del protagonista regido por la retórica de clase, su desprecio por las masas y la violencia, poniendo énfasis en la construcción poética de esta última a través de las imágenes, del lenguaje y del concepto de raza entre otros, Inzaurralde retoma la presencia en $L a$ virgen de los sicarios de uno de los textos canónicos de la literatura hispanoamericana como lo es el Ariel (1900) de Rodó, recordándonos que bastaron solo cien años para que la "ciudad perfecta" de Rodó se convirtiera en la "ciudad maldita" de Vallejo (193).

En el cuarto estudio se analiza de forma general la obra de Roberto Bolaño poniendo énfasis en la "experiencia de la derrota" (195) como resultado de los cambios sufridos en América Latina desde la década de los setenta. Se destaca también la tensión constante de la narrativa bolañesca ligada a los conceptos de infierno (Alighieri, Strindberg, Benjamin, Agamben) así como a la experiencia del exilio en sus distintas interpretaciones: positivas (viaje) y negativas (expulsión). Inzaurralde relaciona también los conceptos de exilio en Onetti y Kundera e incluye las características clásicas del exiliado de Bolaño. A lo anterior se añaden otros hilos conductores de la narrativa de Bolaño como lo son el concepto del mal y el terror apoyándose principalmente en las teorías de Badiou y Benjamin. Fiel a una actitud crítica, Inzaurralde se aleja de las posturas posmodernas del fracaso desde las que se estudia a Bolaño para proponer la necesidad de una "nueva ficción emancipadora" (249), abriendo así las posibilidades para aprehender la vasta obra de este autor.

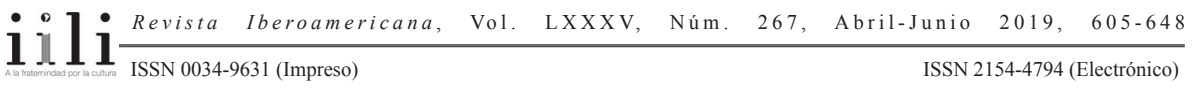


El último estudio se dedica a La novela luminosa (2005) de Mario Levrero y en él, Inzaurralde lleva al lector de la mano por la genética de este texto que será publicado a título póstumo y que nos permite seguir la evolución de la escritura, así como las referencias intertextuales presentes en el texto de Levrero. Aunado a lo anterior, la experimentación, así como la construcción de la figura del narrador son finamente reconfiguradas y renuevan el interés por redescubrir a este autor uruguayo cuya obra quedó inconclusa y que se completa gracias a una lectura activa tal y como propone Inzaurralde.

La escritura y la furia, deja patente que a pesar de su "tendencia a desaparecer", la crítica literaria todavía tiene aseguradas más horas de vida por delante.

Diana Castilleja

Vrije Universiteit Brussel

Université Saint-Louis - Bruxelles

Benigno Trigo. Malady and Genius: Self-Sacrifice in Puerto Rican Literature. Albany: State University of New York Press, 2016. 228 pp. ISBN 978-1-4384-6157-1.

Según Bryan S. Turner, la modernidad se considera el comienzo de una "sociedad somática" (The Body \& Society), una sociedad dentro de la cual los principales problemas políticos y morales se articulan y se expresan a través del cuerpo. Desde finales del siglo XIX, el cuerpo ha servido como una metáfora para la discusión teórica de las dinámicas sociales, culturales y psicológicas. Comenzando con la teoría psicoanalítica a fines del siglo XIX y la fenomenología a principios del siglo XX, el cuerpo ha desempeñado un papel importante en las dinámicas entre el individuo y el mundo. Los teóricos posmodernos concedieron importancia al cuerpo como el lugar de negociación entre el individuo y el entorno externo, pero en sus análisis ven el límite entre ambos como cada vez más transparente. Según varios teóricos posmodernos, la superficie del cuerpo es tanto un lugar de exterioridad como de interioridad, una superficie plana sobre la cual se producen el cuerpo y el mundo. Con el paso de la teoría moderna a la postmoderna, y a partir de las transformaciones en la experiencia

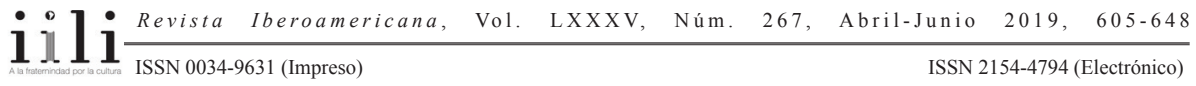

